OPEN ACCESS

Edited by:

Michael Strupp,

Ludwig Maximilian University of

Munich, Germany

Reviewed by:

lan S. Curthoys,

University of Sydney, Australia

Konrad P. Weber,

University of Zurich, Switzerland

*Correspondence:

Angelica Perez Fornos

Angelica.Perez-Fornos@hcuge.ch

Specialty section:

This article was submitted to

Neuro-Otology,

a section of the journal

Frontiers in Neurology

Received: 20 March 2020

Accepted: 28 April 2020

Published: 27 May 2020

Citation:

Guyot J-P, Guinand N and Perez Fornos A (2020) Tribute to

Bernard Cohen - Whose Pioneering Work Made the Vestibular Implant

Possible. Front. Neurol. 11:452.

doi: 10.3389/fneur.2020.00452

\section{Tribute to Bernard Cohen - Whose Pioneering Work Made the Vestibular Implant Possible}

\author{
Jean-Philippe Guyot, Nils Guinand and Angelica Perez Fornos* \\ Division of ENT and Head-and-Neck Surgery, Geneva University Hospitals, Geneva, Switzerland
}

Keywords: vestibular system, vestibular loss, vestibulopathy, electrical stimulation, vestibular implant, cochlear implant, neuroprosthesis, nystagmus

It is estimated that $\sim 1.8$ million adults suffer from a severe or total bilateral vestibular deficit worldwide (1). Despite the dramatic consequences of the disease on the physical, emotional, and social functioning (2) in adults as well as its negative effects on the development of children born without vestibular function (3), there is no effective treatment for these patients (4). It was not until the mid-1990s that the idea of developing a neuroprosthesis that provides position and motion information to the brain using a concept comparable to the cochlear implant was born. Undoubtedly, this idea was based on the pioneering work of Bernard Cohen and his colleague JunIchi Suzuki who, in the sixties, obtained and precisely described the reflex responses obtained by electric stimulation of the ampullary nerves in rabbits, pigeons, cats, and monkeys (5-8). Three decades later, Merfeld and Gong demonstrated that a rotation signal could be delivered to the nervous system using a piezoelectric gyroscope modulating the frequency of electrical signals according to the direction and the speed of head movements in guinea pigs $(9,10)$. It was time to move on to experimentation in humans.

It then seemed reasonable to us to see whether it was possible to duplicate the experiences of Cohen and Suzuki (5-8) in humans. In other words, we wanted to explore the possibility of generating vestibular reflexes upon electrical stimulation of the branches of the vestibular nerve, while at the same time limiting possible risks of hearing loss caused by the introduction of electrodes in the inner ear. Surgical approaches to the posterior and lateral ampullary nerves were developed (11) and, in 2004, the first electrical stimulation trials were performed in local anesthesia in patients undergoing surgery for cochlear implantation or suffering from Menière's disease eligible for a surgical labyrinthectomy.

These experiments showed that it was possible to access the branches of the vestibular nerve surgically without opening the labyrinth and that, not surprisingly, and in agreement with the pioneering works of Cohen and Suzuki, the nystagmic responses were aligned with the plane of the stimulated canal (12-14). Since 2007, this has led to several implantations of our vestibular implant prototypes in humans, with the demonstration of partial restoration of the vestibular function (11). Other groups in Baltimore and Washington followed with promising outcomes $(15,16)$.

We owe a lot to Bernard Cohen for his contribution in the field of vestibular physiology which opened the door to the development of a vestibular implant. This raises high hopes to improve the quality of life of patients suffering from a bilateral deficit. As for us, we were thrilled to present these first results at the meeting of the Association Research in Otolaryngology in Baltimore in 2011: Bernard Cohen was part of the audience. Thank you for the inspiration and encouragement, Sir ! 
We were sad to learn that he passed away in Mont Sinai Hospital on November 272019 the same hospital where he had initiated the original studies almost six decades ago.

\section{REFERENCES}

1. Ward BK, Agrawal Y, Hoffman HJ, Carey JP, Della Santina CC. Prevalence and impact of bilateral vestibular hypofunction: results from the 2008 US national health interview survey. JAMA Otolaryngol Head Neck Surg. (2013) 139:803-10. doi: 10.1001/jamaoto.2013.3913

2. Guinand N, Boselie F, Guyot JP, Kingma H. Quality of life of patients with bilateral vestibulopathy. Ann Otol Rhinol Laryngol. (2012) 121:4717. doi: $10.1177 / 000348941212100708$

3. Wiener-Vacher SR, Hamilton DA, Wiener SI. Vestibular activity and cognitive development in children: perspectives. Front Integr Neurosci. (2013) 7:92. doi: $10.3389 /$ fnint.2013.00092

4. Zingler VC, Cnyrim C, Jahn K, Weintz E, Fernbacher J, Frenzel C, et al. Causative factors and epidemiology of bilateral vestibulopathy in 255 patients. Ann Neurol. (2007) 61:524-32. doi: 10.1002/ana.21105

5. Suzuki JI, Cohen B. Head, eye, body and limb movements from semicircular canal nerves. Exp Neurol. (1964) 10:393405. doi: 10.1016/0014-4886(64)90031-7

6. Cohen B, Suzuki JI, Bender MB. Eye movements from semicircular canal nerve stimulation in the cat. Ann Otol Rhinol Laryngol. (1964) 73:15369. doi: 10.1177/000348946407300116

7. Suzuki JI, Cohen B, Bender MB. Compensatory eye movements induced by vertical semicircular canal stimulation. Exp Neurol. (1964) 9:13760. doi: 10.1016/0014-4886(64)90013-5

8. Cohen B, Suzuki JI. Eye movements induced by ampullary nerve stimulation. Am J Physiol. (1963) 204:347-51. doi: 10.1152/ajplegacy.1963.204.2.347

9. Gong W, Merfeld DM. Prototype neural semicircular canal prosthesis using patterned electrical stimulation. Ann Biomed Eng. (2000) 28:57281. doi: $10.1114 / 1.293$

10. Gong W, Merfeld DM. System design and performance of a unilateral horizontal semicircular canal prosthesis. IEEE Trans Biomed Eng. (2002) 49:175-81. doi: 10.1109/10.979358

11. Guyot JP, Perez Fornos A. Milestones in the development of a vestibular implant. Curr Opin Neurol. (2019) 32:14553. doi: 10.1097/WCO.0000000000000639

\section{AUTHOR CONTRIBUTIONS}

J-PG, NG, and AP wrote and approved the manuscript.

12. Wall C III, Kos MI, Sigrist A, Delaspre O, Guyot JP. Electrical stimulation of the posterior ampularis nerve in an alert patient: preliminary results. In: Barany Society, XXIII International Congress. Paris (2004).

13. Wall C III, Kos MI, Guyot JP. Eye movements in response to electric stimulation of the human posterior ampullary nerve. Ann Otol Rhinol Laryngol. (2007) 116:369-74. doi: 10.1177/0003489407116 00509

14. Guyot J-P, Sigrist A, Pelizzone M, Feigl, GC, Kos MI. Eye movements in response to electric stimulation of the lateral and superior ampullary nerves. Ann Otol Rhinol Laryngol. (2011) 120:81-7. doi: 10.1177/000348941112000202

15. Boutros PJ, Schoo DP, Rahman M, Valentin NS, Chow MR, Ayiotis AI, et al. Continuous vestibular implant stimulation partially restores eyestabilizing reflexes. JCI Insight. (2019) 4:128397. doi: 10.1172/jci.insight. 128397

16. Phillips JO, Ling L, Nie K, Jameyson E, Phillips CM, Nowack $\mathrm{AL}$, et al. Vestibular implantation and longitudinal electrical stimulation of the semicircular canal afferents in human subjects. J Neurophysiol. (2015) 113:3866-92. doi: 10.1152/jn.00171. 2013

Conflict of Interest: The authors declare received research and travel grants from MED-EL Elektromedizinische Geräte GMBH (Innsbruck, Austria).

The remaining authors declare that the research was conducted in the absence of any commercial or financial relationships that could be construed as a potential conflict of interest.

Copyright (c) 2020 Guyot, Guinand and Perez Fornos. This is an open-access article distributed under the terms of the Creative Commons Attribution License (CC BY). The use, distribution or reproduction in other forums is permitted, provided the original author(s) and the copyright owner(s) are credited and that the original publication in this journal is cited, in accordance with accepted academic practice. No use, distribution or reproduction is permitted which does not comply with these terms. 